ARTICLE

Received 22 Nov 2013 | Accepted 8 Jul 2014 | Published 20 Aug $2014 \quad$ DOl: 10.1038/ncomms5624

\title{
Differentiated availability of geochemical mercury pools controls methylmercury levels in estuarine sediment and biota
}

Sofi Jonsson ${ }^{1,2}$, Ulf Skyllberg ${ }^{3}$, Mats B. Nilsson ${ }^{3}$, Erik Lundberg ${ }^{2}$, Agneta Andersson ${ }^{2,4}$ \& Erik Björn ${ }^{1}$

Neurotoxic methylmercury ( $\mathrm{MeHg}$ ) formed from inorganic divalent mercury $\left(\mathrm{Hg}^{\mathrm{Il}}\right)$ accumulates in aquatic biota and remains at high levels worldwide. It is poorly understood to what extent different geochemical $\mathrm{Hg}$ pools contribute to these levels. Here we report quantitative data on $\mathrm{MeHg}$ formation and bioaccumulation, in mesocosm water-sediment model ecosystems, using five $\mathrm{Hg}^{\prime l}$ and $\mathrm{MeHg}$ isotope tracers simulating recent $\mathrm{Hg}$ inputs to the water phase and $\mathrm{Hg}$ stored in sediment as bound to natural organic matter or as metacinnabar. Calculations for an estuarine ecosystem suggest that the chemical speciation of $\mathrm{Hg}^{\prime \prime}$ solid/adsorbed phases control the sediment $\mathrm{Hg}$ pool's contribution to $\mathrm{MeHg}$, but that input of $\mathrm{MeHg}$ from terrestrial and atmospheric sources bioaccumulates to a substantially greater extent than $\mathrm{MeHg}$ formed in situ in sediment. Our findings emphasize the importance of $\mathrm{MeHg}$ loadings from catchment runoff to $\mathrm{MeHg}$ content in estuarine biota and we suggest that this contribution has been underestimated.

\footnotetext{
${ }^{1}$ Department of Chemistry, Umeå University, SE-901 87 Umeå, Sweden. ${ }^{2}$ Umeå Marine Sciences Centre, Umeå University, SE-910 20 Hörnefors, Sweden.

${ }^{3}$ Department of Forest Ecology and Management, Swedish University of Agricultural Sciences, SE-901 83 Umeå, Sweden. ${ }^{4}$ Department of Ecology and Environmental Science, Umeå University, SE-901 87 Umeå, Sweden. Correspondence and requests for materials should be addressed to E.B.

(email: erik.bjorn@chem.umu.se).
} 
M ethylmercury $(\mathrm{MeHg})$ accumulated in estuarine fish is a major concern for wildlife and human health ${ }^{1}$. It may originate from direct atmospheric and terrestrial $\mathrm{MeHg}$ loading or may form in estuaries from inorganic divalent $\mathrm{Hg}$ $\left(\mathrm{Hg}^{\mathrm{II}}\right)^{2-4}$. Also $\mathrm{Hg}^{\mathrm{II}}$ is deposited to estuaries from the atmosphere or runoff and partly accumulates over time in sediment as various solid and adsorbed chemical forms ${ }^{1}$. The extent to which these different geochemical $\mathrm{MeHg}$ and $\mathrm{Hg}^{\text {II }}$ pools, a term that we here define as $\mathrm{Hg}$ with different chemical speciation and/or environmental compartment localization, contribute to $\mathrm{MeHg}$ in sediment and biota is largely unknown ${ }^{5}$. Improved knowledge is critical for our understanding of the $\mathrm{Hg}$ biogeochemical cycle, to manage $\mathrm{Hg}$ pollutant issues and to predict the impact of changes in $\mathrm{Hg}$ emission rates, climate and anthropogenic land use.

Formation of $\mathrm{MeHg}$ is a biotic process carried out by specific strains of sulphate- and iron-reducing bacteria, methanogens and firmicutes ${ }^{4,6-8}$, and mediated via the $h g c A$ and $h g c B$ genes ${ }^{7}$. Such bacteria have been suggested to take up and methylate specific aqueous $\mathrm{Hg}^{\mathrm{II}}$-complexes, that is, neutral $\mathrm{Hg}^{\mathrm{II}}$ sulphide ${ }^{3}$ (although recently questioned ${ }^{9,10}$ ) or low-molecular-mass $\mathrm{Hg}^{\mathrm{II}}$ thiol complexes ${ }^{11,12}$. Only a minor fraction of $\mathrm{Hg}^{\mathrm{II}}$ in natural sediment and waters is present in the aqueous phase, and the partitioning to the solid phase $\left(\mathrm{K}_{\mathrm{D}}\right)$ is typically in the range $10^{5}-10^{6} 1 \mathrm{~kg}^{-1}$ (ref. 13). To sustain typically observed methylation rates, aqueous concentrations of $\mathrm{Hg}^{\mathrm{II}}$ must continuously be resupplied by dissolution/desorption from the much more abundant solid/adsorbed $\mathrm{Hg}^{\mathrm{II}}$ phases ${ }^{14}$. We recently showed, using small-scale sediment slurry experiments, that the $\mathrm{Hg}^{\mathrm{II}}$ methylation rate constant $\left(k_{\mathrm{m}}\right)$ differed up to 2 orders of magnitude depending on the $\mathrm{Hg}^{\mathrm{II}}$ solid phase speciation ${ }^{14}$. In addition to factors controlling $\mathrm{MeHg}$ formation, concentration of $\mathrm{MeHg}$ in biota is influenced by factors regulating the entry of $\mathrm{MeHg}$ into the food web and its trophic transfer. Irrespective of whether the cellular uptake mechanisms involve dissolved $\mathrm{MeHg}$ complexes in surrounding water or in the gut, the uptake is governed by the chemical speciation of dissolved $\mathrm{MeHg}$ and to a large extent limited by sorption to particles or complexation with dissolved organic ligands, which are not bioavailable ${ }^{15-17}$. Yet our understanding of processes controlling the availability of different geochemical MeHg pools, and the quantitative importance of such processes at the ecosystem level, remains insufficient.

Generation of quantitative data on the availability for $\mathrm{MeHg}$ formation and bioaccumulation of specific geochemical $\mathrm{Hg}$ pools relevant for ecosystem level models requires experimental systems that represent natural conditions with respect to factors critical for $\mathrm{MeHg}$ formation (that is, natural sediment redox gradients, relevant bacterial community structure and a continuous supply of autochthonous organic carbon to the benthic zone) and bioaccumulation (relevant pelagic and benthic food webs). The experimental procedure is thus challenging, however, by the use of a new mesocosm experimental setup enabling the study of model ecosystems with intact sediment cores, and combining it with a recently developed isotope tracer methodology ${ }^{14}$, we were able to meet these requirements.

We show that the solid/adsorbed phase chemical speciation of $\mathrm{Hg}^{\mathrm{II}}$ in the sediment and catchment runoff loading rate of $\mathrm{MeHg}$ are the major factors controlling $\mathrm{MeHg}$ quantity in estuarine sediment and biota. The contribution to $\mathrm{MeHg}$ in sediment and biota from long-term accumulated $\mathrm{Hg}$ pools in sediment is controlled by the solid/adsorbed phase chemical speciation of $\mathrm{Hg}$, where $\mathrm{Hg}^{\mathrm{II}}$ bonded to thiol groups in natural organic matter $(\mathrm{NOM})$ is ten times more available for methylation than metacinnabar $(\beta-\mathrm{HgS})$. Further, recent inputs of $\mathrm{MeHg}$ from terrestrial runoff (or to a minor extent from atmospheric deposition) exhibit a 5-250 times higher availability for bioaccumulation as compared with $\mathrm{MeHg}$ formed in situ in the sediment. We propose that the contribution of MeHg loadings from catchment runoff to $\mathrm{MeHg}$ content in estuarine biota has, in many systems, been underestimated.

\section{Results}

Mesocosm experimental system and $\mathrm{Hg}$ isotope tracers. Model ecosystems with intact sediment cores $(\sim 0.2 \times 0.63 \mathrm{~m} \emptyset)$ submerged in brackish water were constructed in high-density polyethylene (HDPE) cylinder mesocosms $(n=3,2,0001$ volume, $5 \mathrm{~m} \times 0.75 \mathrm{~m} \varnothing)$ and controlled with respect to temperature, light exposure and nutrient additions during an experimental period of 2 months. Isotopically enriched $\mathrm{Hg}^{\mathrm{I}}$ and $\mathrm{MeHg}$ tracers were injected across the sediment cores (surface injection density of 1.1 injection per $\mathrm{cm}^{2}$ and injection depth of $0.5 \mathrm{~cm}$ ) as solid/adsorbed chemical forms relevant for suboxic/anoxic conditions ${ }^{14}$ (metacinnabar: $\beta-{ }^{200} \mathrm{HgS}_{\text {sed }}$ and complexes with thiol groups in NOM: ${ }^{201} \mathrm{Hg}^{\mathrm{II}}-\mathrm{NOM}_{\text {sed }}$ and $\mathrm{Me}^{198} \mathrm{Hg}-\mathrm{NOM}_{\text {sed }}$ ) to simulate accumulated sediment $\mathrm{Hg}^{\mathrm{II}}$ and $\mathrm{MeHg}$ pools. A second set of tracers were added to the brackish water as labile aqueous $\mathrm{Hg}^{\mathrm{II}}$ and $\mathrm{MeHg}$ complexes $\left({ }^{204} \mathrm{Hg}_{\mathrm{wt}}^{\mathrm{II}}\right.$ and $\left.\mathrm{Me}^{199} \mathrm{Hg}_{\mathrm{wt}}\right)$ to simulate recent $\mathrm{Hg}$ inputs to the water phase (from atmospheric deposition and catchment runoff), see Fig. 1. The MeHg/HgII molar ratio (Supplementary Methods, Supplementary Fig. 1) determined in sediment samples was used as a quantitative measure of the rate of net $\mathrm{MeHg}$ formation (Fig. 2a,b) and remained fairly stable from the second week of the experiment. Bioaccumulation of $\mathrm{MeHg}$ in plankton (seston size fractions), amphipods and benthic invertebrates collected at the end of the experiment was quantified by the Biota-Sediment Accumulation Factor (BSAF; MeHg concentration ratio between biota (pmolg ${ }^{-1}$ dry weight (d.w.)) and sediment ( pmolg $^{-1}$ d.w.; Fig. 2c-e).

$\mathrm{MeHg}$ net formation. Net $\mathrm{MeHg}$ formation (average $\mathrm{MeHg} /$ $\mathrm{Hg}^{\mathrm{II}} \pm$ confidence interval $\left.(\mathrm{CI}), p=0.05\right)$ of the ${ }^{201} \mathrm{Hg}^{\mathrm{I}}-\mathrm{NOM}_{\text {sed }}$ tracer $(0.0084 \pm 0.0025)$ was higher (14-18 times) than of the $\beta$ ${ }^{200} \mathrm{HgS}_{\text {sed }}$ tracer $(0.00049 \pm 0.00013$; Fig. 2a). This result is in line with our previous small-scale experiments ${ }^{14}$ and reasonable given the low solubility of $\beta-\mathrm{HgS}(\mathrm{s})^{10}$. Further, we observed a MeHg/ $\mathrm{Hg}^{\mathrm{II}}$ ratio for ${ }^{204} \mathrm{Hg}^{\mathrm{II}}{ }_{\mathrm{wt}}(0.027 \pm 0.012)$ that was $3-4$ and $40-70$ times higher than for ${ }^{201} \mathrm{Hg}^{\mathrm{II}}-\mathrm{NOM}_{\text {sed }}$ and $\beta-{ }^{200} \mathrm{HgS}_{\text {sed }}$, respectively (Fig. 2a). Separate incubation experiments with tracer-spiked mesocosm water (which remained oxic throughout the entire experiment) showed that $\mathrm{MeHg}$ formation in the water

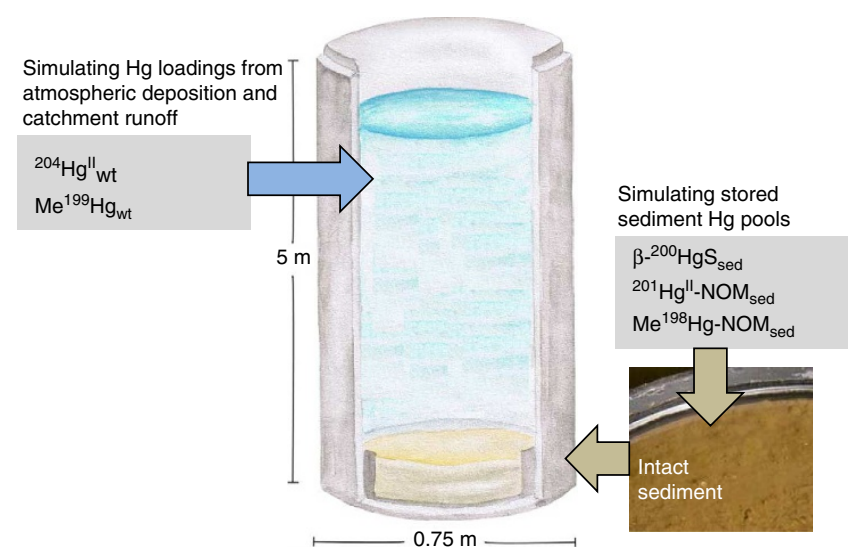

Figure 1 | Illustration of the experimental setup. Schematic illustration of the $\mathrm{Hg}$ isotope tracer addition and representation in the mesocosm systems. 

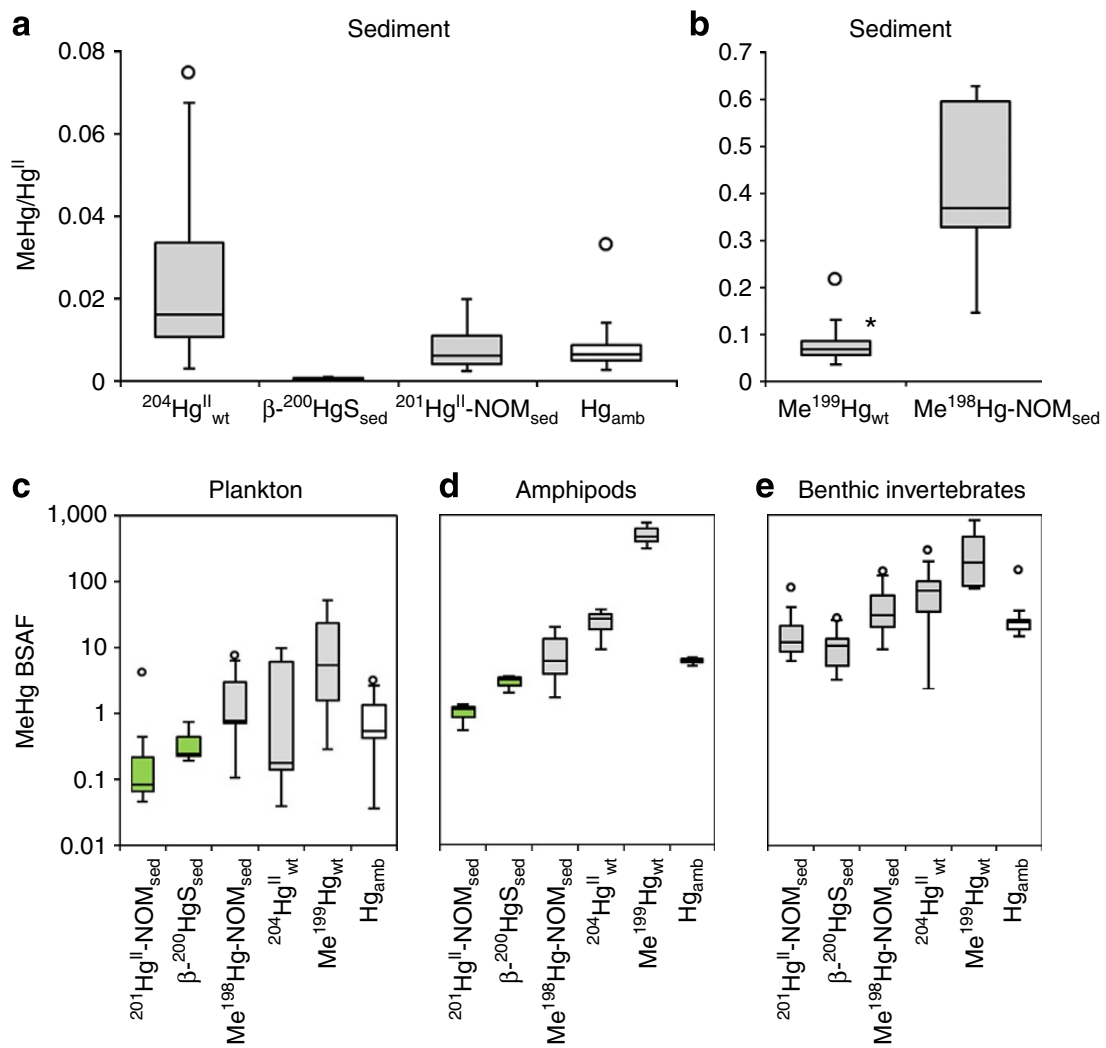

Figure 2 | MeHg/Hg" molar ratio and MeHg Biota-Sediment Accumulation Factor (BSAF). Box plots showing 25th, 50th and 75th percentiles (horizontal bars), 1.5 interquartile ranges (error bars) and maximum outlier (open circles) for $\mathrm{MeHg} / \mathrm{Hg}$ "l molar ratio determined in mesocosm sediment samples from days 10 to 52 of the experiment for (a) $\mathrm{Hg}^{\prime \prime}$ tracers and ambient $\mathrm{Hg}$ (white bar) and (b) MeHg tracers. Asterisk indicates calculated minimum ratio for $\mathrm{Me}^{199} \mathrm{Hg}_{\mathrm{wt}}$ based on a theoretical $\left[\mathrm{Hg}^{l l}\right]$ value if $100 \%$ of the tracer had deposited to the sediment. Corresponding box plots for BSAF of $\mathrm{MeHg}$ from $\mathrm{Hg}^{\mathrm{Il}}$ and $\mathrm{MeHg}$ tracers and ambient $\mathrm{MeHg}$ (white bars) in (c) plankton (seston size fractions 50-100, 100-300 and >300 $\mu \mathrm{m}$ ),

(d) amphipods and (e) benthic invertebrates (Chironomids, Polychaetes and bivalves) collected at the end of the experiment (day 57). Green coloured boxes indicate limit of detection data.

phase was negligible. We thus conclude that the ${ }^{204} \mathrm{Hg}^{\mathrm{II}}$ wt tracer was methylated in the sediment. The average residence time of this tracer in the water column was 10-15 days (Supplementary Fig. 2a), which highly exceeds the time of $\sim 10 \mathrm{~h}$ to maximum a few days ${ }^{18,19}$ typically needed for $\mathrm{Hg}^{\mathrm{II}}$ to rearrange from its predominant labile $\mathrm{Hg}(\mathrm{OH})_{2}^{0}$ complex to the thermodynamically most stable NOM coordinated complexes. Under the existing oxic conditions in the DOC-rich water column, a coordination with two thiols (RSH): $\mathrm{Hg}(\mathrm{SR})_{2}$ in NOM would be the by far dominant complex $^{20}$ (Supplementary Table 1). Therefore, the ${ }^{204} \mathrm{Hg}^{\mathrm{II}}{ }_{\mathrm{wt}}$ tracer should have depostited to the sediment as $\mathrm{Hg}(\mathrm{SR}-\mathrm{NOM})_{2}$ complexes either after flocculation/aggregation of NOM and/or after adsorption to water column particles ${ }^{21}$. Based on this argumentation, we regard the ${ }^{204} \mathrm{Hg}^{\mathrm{II}}$ wt tracer to be representative of $\mathrm{Hg}^{\mathrm{II}}$ recently deposited from the atmosphere and from terrestrial runoff. It cannot be ruled out that differences in the character of NOM in the water column of the mescocoms (a mixture of allochthonous and autochthonous NOM to which ${ }^{204} \mathrm{Hg}^{\mathrm{II}}$ wt can be expected to complex) and the pure terrestrial NOM used in the ${ }^{201} \mathrm{Hg}^{\mathrm{II}}-\mathrm{NOM}_{\text {sed }}$ tracer are important for the higher $\mathrm{MeHg} / \mathrm{Hg}^{\mathrm{II}}$ ratio observed for the ${ }^{204} \mathrm{Hg}^{\mathrm{II}}$ wt tracer. This is, however, not likely given that terrestrial NOM constitutes more than $75 \%$ of the total DOC in the estuary where the mesocosm brackish water was collected ${ }^{22}$. It also needs to be considered that the ${ }^{204} \mathrm{Hg}^{\mathrm{II}}$ wt tracer deposited to the surface of the sediment during an extended time of the experiment, whereas ${ }^{201} \mathrm{Hg}^{\mathrm{II}}$ $\mathrm{NOM}_{\text {sed }}$ was injected at a sediment depth of $0.5 \mathrm{~cm}$ at the start of the experiment. The pore water chemistry and bacterial activity usually change drastically with depth close to the surface in natural sediments ${ }^{23}$. In separate experiments, $k_{\mathrm{m}}$ values determined in sediment slurries (from $4 \mathrm{~cm} \varnothing$ sediment cores sub-sampled from the mesocosms) were fairly constant $(0.017$ $\left.0.023 \mathrm{~d}^{-1}\right)$ in the top $4 \mathrm{~cm}(1 \mathrm{~cm}$ resolution) and did thus not support vertical discrepancy to explain the differences in net $\mathrm{MeHg}$ formation. It may, however, be that the resolution $(1-\mathrm{cm}$ layers) was not fine enough to encapture the commonly encountered high rate of $\mathrm{Hg}^{\mathrm{II}}$ methylation in the sedimentwater interface.

Our results contribute to clarify the critical but uncertain question if recent $\mathrm{Hg}^{\mathrm{II}}$ deposits to the ecosystem water phase are more available for methylation than previous $\mathrm{Hg}$ deposits accumulated in the system ${ }^{24,25}$ (Figs $2 \mathrm{a}$ and 3a). Our data support such a hypothesis but also shows that as a general statement this would be too simplistic. Depending on the chemical speciation of $\mathrm{Hg}^{\mathrm{II}}$, the difference can be large (40-70 times) or relatively small (3-4 times) if the sediment pool is dominated by $\beta-\mathrm{HgS}(\mathrm{s})$ or by $\mathrm{Hg}(\mathrm{SR}-\mathrm{NOM})_{2}$.

MeHg degradation. Based on previous incubation experiments ${ }^{24,26}$ with dissolved labile isotope tracers (and assuming pseudo-first order rate laws for formation and degradation of $\mathrm{MeHg}$ ), half-life (ln $2 / k_{\mathrm{d}}$, where $k_{\mathrm{d}}$ is the $\mathrm{MeHg}$ demethylation rate constant) and turnover $\left(k_{\mathrm{m}}+k_{\mathrm{d}}\right)^{-1}$ of $\mathrm{MeHg}$ in natural sediments have been estimated to be on the order of 1-3 days. Based on this, the $\mathrm{MeHg}$ molecule has been considered not to 

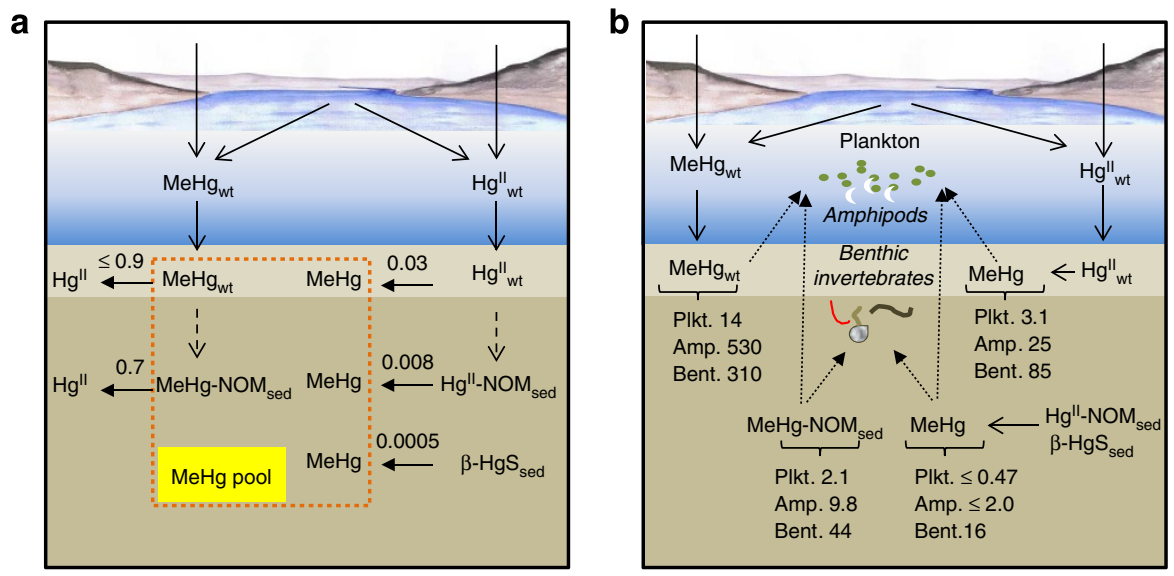

Figure 3 | Illustration of net formation and bioaccumulation of $\mathbf{M e H g}$ from different geochemical $\mathbf{H g}$ pools. (a) Net formation (from $\mathrm{Hg}$ " tracers) and net degradation (from MeHg tracers) of $\mathrm{MeHg}$ in sediment $(0-1.5 \mathrm{~cm})$ from stored sediment pools of $\mathrm{Hg}^{\mathrm{II}}\left(\mathrm{Hg}^{\prime \prime}-\mathrm{NOM}_{\text {sed }}, \beta-\mathrm{HgS}\right.$ sed $)$ and $\mathrm{MeHg}$ $\left(\mathrm{MeHg}-\mathrm{NOM}_{\mathrm{sed}}\right)$ and from recent $\mathrm{Hg}^{\mathrm{Il}}\left(\mathrm{Hg}^{\prime \prime}{ }_{\mathrm{wt}}\right)$ and $\mathrm{MeHg}\left(\mathrm{MeHg}_{\mathrm{wt}}\right)$ loadings to the aquatic system via atmospheric deposition or terrestrial runoff deposited to the sediment surface. Values are given as $\mathrm{MeHg} / \mathrm{Hg}^{\prime \prime}$ molar ratio for $\mathrm{Hg}^{\prime \prime}$ tracers and $\mathrm{Hg}^{\prime \prime} /\left(\mathrm{Hg}{ }^{\prime \prime}+\mathrm{MeHg}\right)$ molar ratio for $\mathrm{MeHg}$ tracers. (b) Biota-Sediment Accumulation Factor for MeHg originating from the different $\mathrm{Hg}$ II and $\mathrm{MeHg}$ tracers for plankton (Plkt., average of 50-100, 100-300, $>300 \mu \mathrm{m}$ seston size fractions), amphipods (Amp.) and benthic invertebrates (Bent., average for Chironomids, Polychaetes and bivalves).

persist or accumulate in natural sediments. Vertical sediment profiles have in some cases demonstrated a close correlation between $\mathrm{MeHg}$ concentration and the $\mathrm{Hg}^{\mathrm{II}}$ methylation rate $^{27}$, in line with the hypothesis of a rapid $\mathrm{MeHg}$ turnover, whereas other studies have indicated that $\mathrm{MeHg}$ might persist longer (up to decades) in sediments ${ }^{28,29}$. If assuming 1-3 days turnover, the $\mathrm{Me}^{198} \mathrm{Hg}-\mathrm{NOM}_{\text {sed }}$ tracer would within $\sim 2$ weeks adopt a similar $\mathrm{MeHg} / \mathrm{Hg}^{\mathrm{II}}$ ratio as our added $\mathrm{Hg}^{\mathrm{II}}$ tracers and ambient $\mathrm{Hg}$ in the mesocosm sediment. In great contrast, we observed a $\mathrm{MeHg} / \mathrm{Hg}^{\mathrm{II}}$ ratio for $\mathrm{Me}^{198} \mathrm{Hg}-\mathrm{NOM}_{\text {sed }}$ that was on average $16-880$ and 50 times higher than for $\mathrm{Hg}^{\mathrm{II}}$ tracers and ambient $\mathrm{Hg}$, respectively, during the 52 days experiment (Fig. 2a,b). This observation indicates a much longer turnover, at least for a significant fraction of $\mathrm{MeHg}$ in sediments. Marvin-Dipasquale et al. ${ }^{30}$ suggested that $\mathrm{MeHg}$ can be sequestered into several pools with different availability for demethylation. The fraction (approximately $30 \%$ if the remaining fraction is assumed to turnover in 1-3 days) of the $\mathrm{Me}^{198} \mathrm{Hg}-\mathrm{NOM}_{\text {sed }}$ tracer that was not readily available for demethylation in our study was still somewhat more efficiently bioaccumulated than $\mathrm{MeHg}$ formed in situ from the ${ }^{201} \mathrm{Hg}^{\mathrm{II}}-\mathrm{NOM}_{\text {sed }}$ and $\beta^{2}{ }^{200} \mathrm{HgS}_{\text {sed }}$ tracers (Figs $2 \mathrm{c}-\mathrm{e}$ and $3 \mathrm{~b}$ ). We suggest that sequestration of $\mathrm{MeHg}$ as thermodynamically stable forms, such as complexes with thiols in NOM (or possibly adsorbed to sulphide minerals), in the sediment partly prevents demethylation yet without preventing $\mathrm{MeHg}$ entering the aquatic food webs. The exact mechanisms leading to the accumulation of persistent $\mathrm{MeHg}$ in sediments are, however, not well understood and their potential importance not well recognized.

MeHg bioaccumulation. We observed a considerably higher (5-250 times) BSAF for $\mathrm{Me}^{199} \mathrm{Hg}_{\mathrm{wt}}$ (Figs 2c-e and $3 \mathrm{~b}$ ), as compared with $\mathrm{Me}^{198} \mathrm{Hg}-\mathrm{NOM}_{\text {sed }}$ and in situ formed $\mathrm{MeHg}$, in both plankton and benthic invertebrates. This, as well as our modelling results discussed below, clearly emphasizes the importance of imported $\mathrm{MeHg}$ for its bioaccumulation in estuarine ecosystems. This MeHg import will consist of a small proportion from direct atmospheric deposition and a large proportion from terrestrial runoff (originating from methylation of atmospherically depositied $\mathrm{Hg}^{\mathrm{II}}$ in catchment soils). Although direct input of $\mathrm{MeHg}$ is highly available for bioaccumulation, in situ formed $\mathrm{MeHg}$ (from atmospheric and runoff $\mathrm{Hg}^{\mathrm{II}}$ inputs) is bioaccumulated to a lower extent.

We propose that this difference in bioaccumulation is mainly a consequence of feeding strategies of specific organisms ${ }^{31,32}$ and differences in the vertical distribution of $\mathrm{MeHg}$ originating from different sources (in our case tracers). The $\mathrm{Me}^{199} \mathrm{Hg}_{w t}$ tracer settles to the oxic sediment surface predominantly as $\mathrm{MeHg}$, whereas for the other tracers, $\mathrm{MeHg}$ is formed (or for the $\mathrm{Me}^{198} \mathrm{Hg}-\mathrm{NOM}_{\text {sed }}$ tracer directly injected) in suboxic/anoxic zones a few millimetre below the sediment surface. The $\mathrm{Me}^{199} \mathrm{Hg}_{\mathrm{wt}}$ tracer will thus have the highest relative $\mathrm{MeHg}$ abundance in both the pelage (where zooplankton feed) and at the surface of the sediment. Amphipods and the benthic invertebrate species present in this study predominately feed on freshly deposited material at the water-sediment interface ${ }^{31}$. The time required for $\mathrm{MeHg}$ to establish its most thermodynamic stable configuration with $\mathrm{NOM}$, as a one-coordinated MeHgSR complex ${ }^{20}$, is expected to be faster than the time required for the two-coordinated $\mathrm{Hg}(\mathrm{SR})_{2}$ complex to form (discussed above). We therefore propose that MeHgSR-NOM complexes controlled the speciation of the $\mathrm{Me}^{199} \mathrm{Hg}_{\mathrm{wt}}$ tracer (Supplementary Table 1) during the vast majority of its average residence time of $\sim 7$ days (Supplementary Fig. 3a) in the water column and that it settled to the sediment predominantly as such complexes. This explanation model is further supported by the fact that the $\mathrm{MeHg}$ Biota Accumulation Factor $\left(\mathrm{g}^{-1}\right.$ d.w., calculated as the average $\mathrm{MeHg}$ concentration in plankton divided by the average concentration in water from day 15) in plankton for the $\mathrm{Me}^{199} \mathrm{Hg}_{\mathrm{wt}}\left(54 \mathrm{lg}^{-1}\right.$ d.w) and ambient $\mathrm{MeHg}\left(23 \mathrm{lg}^{-1}\right.$ d.w; the only pools with detectable $\mathrm{MeHg}$ concentration in water) exhibited a smaller difference (factor of 2) than did BSAF (factor of 17) for $\mathrm{Me}^{199} \mathrm{Hg}_{\mathrm{wt}}$ (14) and ambient $\mathrm{MeHg}$ (0.8). This indicate that there was likely no significant difference in chemical speciation or availability of $\mathrm{Me}^{199} \mathrm{Hg}$ and ambient $\mathrm{MeHg}$ dissolved in the water column, but that a larger fraction of $\mathrm{MeHg}$ from the $\mathrm{Me}^{199} \mathrm{Hg}_{\mathrm{wt}}$ tracer was distributed to the water column and the sedimentwater interface as compared with ambient $\mathrm{MeHg}$, and likely also the other Hg tracers.

Mercury mass balance modelling. In this work, we provide the first quantitative data demonstrating how geochemical pools of 
$\mathrm{Hg}^{\mathrm{II}}$ and $\mathrm{MeHg}$ differ with respect to their availability for $\mathrm{MeHg}$ formation/degradation (Fig. 3a) and bioaccumulation (Fig. 3b). We evaluated to what extent these differences control $\mathrm{MeHg}$ concentrations in sediment and biota for estuarine ecosystems. Briefly, we applied the determined $\mathrm{MeHg} / \mathrm{Hg}^{\mathrm{II}}$ ratios and BSAFs (Fig. 3) and estimated pool sizes and fluxes of $\mathrm{Hg}^{\mathrm{II}}$ and $\mathrm{MeHg}$ for the Öre Estuary (Table 1) in a simple mass balance model (equations (1) and (2)). Four scenarios, differing in $\mathrm{Hg}^{\mathrm{II}}$ solid/ adsorbed phase speciation (scenario A1 and A2) or $\mathrm{MeHg}$ and $\mathrm{Hg}^{\mathrm{II}}$ loading rates (scenario $\mathrm{Al}, \mathrm{B}$ and $\mathrm{C}$ ), were postulated. These models exhibit qualitative features recognized as critical, but hitherto not included, in $\mathrm{Hg}$ biogeochemical modelling.

It is evident that because of differentiated availability for $\mathrm{MeHg}$ formation and bioaccumulation, specific $\mathrm{Hg}$ pools are predicted to contribute differently to $\mathrm{MeHg}$ concentration in sediment and biota (Fig. 4). The solid/adsorbed phase chemical speciation of $\mathrm{Hg}^{\mathrm{II}}$ in the sediment is a major controlling factor for $\mathrm{MeHg}$ levels in sediment and biota. As illustrated by scenarios A1 and A2, a $[\beta-\mathrm{HgS}]:\left[\mathrm{Hg}^{\mathrm{II}}-\mathrm{NOM}\right]$ molar ratio in the sediment of $30: 70$ compared with 70:30 would, for the same total sediment $\mathrm{Hg}^{\mathrm{II}}$ concentration, almost double the total amount of $\mathrm{MeHg}$ in the sediment and increase MeHg levels in biota by approximately $15-$ $50 \%$. The 'persistent' MeHg pool (purple bars in Fig. 4) is predicted to largely contribute to $\mathrm{MeHg}$ in sediment and biota for all the postulated scenarios. Further research is warranted to clarify if the build-up of this pool in sediments is simply a result of formation of thermodynamically stable $\mathrm{MeHg}-\mathrm{NOM}$ complexes or if additional processes control the size of this pool.

Comparing scenario $\mathrm{B}$ to $\mathrm{A} 1$, coupled with the findings of others $^{33,34}$, suggest that $\mathrm{MeHg}$ levels in sediment and biota in estuarine ecosystems could be highly sensitive to variations in catchment runoff. We modelled the effect of a twofold increase in $\mathrm{Hg}^{\mathrm{II}}+\mathrm{MeHg}$ runoff loading, which, for the Öre Estuary, predicts a rapid increase of $\mathrm{MeHg}$ in biota by $40-80 \%$ ( $\mathrm{t}_{0}$, scenario B) and a $80-90 \%$ increase when the sediment layer simulated as active for $\mathrm{MeHg}$ formation and bioaccumulation in our model $(0-1.5 \mathrm{~cm})$ is fully replenished $\left(t_{\mathrm{R}}\right.$, scenario $\left.\mathrm{B}\right)$. These results further emphasize the potentially large negative effects on $\mathrm{MeHg}$ levels in estuarine biota caused by increased terrestrial runoff following, for example, climate change-induced increases in precipitation or permafrost thaw ${ }^{35}$ and/or anthropogenic land use changes like forest clear-cutting ${ }^{36}$ or wetland drainage ${ }^{37}$. It should be noted that if, in contrast to our results, we assume a uniform availability for $\mathrm{MeHg}$ formation and bioaccumulation of the different geochemical Hg pools, the direct contributions from catchment and atmospheric pools to the total $\mathrm{MeHg}$ in biota are predicted to be less than $2 \%$.

\begin{tabular}{|c|c|c|c|c|}
\hline Source & A1 & A2 & B & c \\
\hline MeHg catchment runoff load & $0.10^{*}$ & A1 & $2 \times \mathrm{A} 1$ & A1 \\
\hline - Hg" catchment runoff load & $1.07^{*}$ & $\mathrm{~A} 1$ & $2 \times A 1$ & A1 \\
\hline MeHg atmospheric load & $0.0043^{*}$ & A1 & A1 & A1 \\
\hline Wg" atmospheric load & $0.36^{*}$ & A1 & A1 & $0.73 \times \mathrm{A} 1$ \\
\hline MeHg sediment pool & $x_{\mathrm{A} 1}$ & $x_{\mathrm{A} 2}$ & $x_{\mathrm{B}}$ & $x_{\mathrm{C}}$ \\
\hline Hgll sediment pool & $79^{\dagger}$ & $79^{\dagger}$ & A1 & A1 \\
\hline$\square[\beta-\mathrm{HgS}]: \square\left[\mathrm{Hg}^{\prime \prime}-\mathrm{NOM}\right]$ & $70: 30$ & $30: 70$ & A1 & A1 \\
\hline $\begin{array}{l}\text { *mol Hg" or } \mathrm{MeHg} \text { per } 4 \text { months. } \\
\text { tmoles } \mathrm{Hg} \text { "I. } \\
\text { țmolar ratio. }\end{array}$ & & & & \\
\hline
\end{tabular}

The response time for $\mathrm{MeHg}$ concentration in fish from a changed atmospheric $\mathrm{Hg}$ loading rate has been predicted from experiments in lake systems to be quick in areas with mainly direct atmospheric loading, but delayed in areas dominated by catchment runoff of $\mathrm{Hg}^{\mathrm{II}}$ and $\mathrm{MeHg}^{25,38}$. Based on our results, we suggest that in estuarine ecosystems with significant catchment $\mathrm{Hg}$ runoff and internal $\mathrm{MeHg}$ production from sediment $\mathrm{Hg}^{\mathrm{II}}$ pools, reduced atmospheric $\mathrm{Hg}^{\mathrm{II}}$ loadings will only have a minor short-term effect on $\mathrm{MeHg}$ levels in biota and that a significant ecosystem recovery will be slow. For the type of estuarine ecosystems modelled here, a $40 \%$ decrease in global anthropogenic $\mathrm{Hg}$ emissions to the atmosphere (UNEPA's
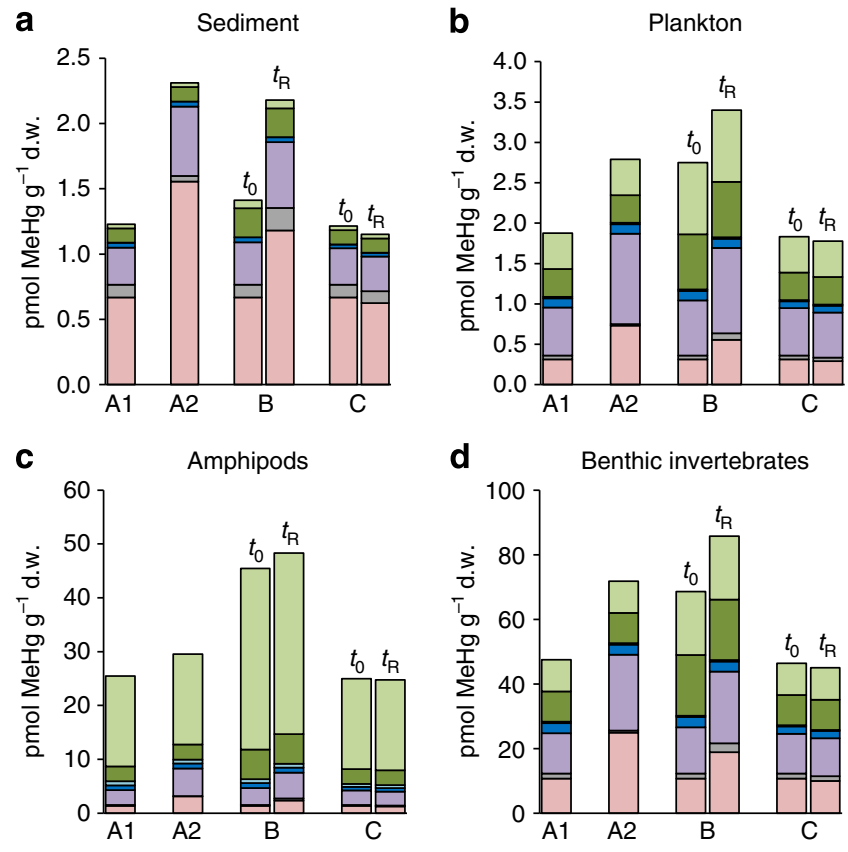

MeHg catchment runoff load, $\quad \mathrm{Hg}^{\prime \prime}$ catchment runoff load, MeHg atmospheric deposition load, - Hgll atmospheric deposition load, MeHg accumulated sediment pool,

$\beta$-HgS accumulated sediment pool, $\quad \mathrm{Hg}^{\prime \prime}-\mathrm{NOM}$ accumulated sediment pool

Figure 4 | Modelled contribution from different geochemical $\mathrm{Hg}$ pools to MeHg in sediment and biota. Predicted contributions from the seven $\mathrm{Hg}^{\prime \prime}$ and $\mathrm{MeHg}$ pools to $\mathrm{MeHg}$ concentrations in (a) $0-1.5 \mathrm{~cm}$ sediment layer, (b) plankton, (c) amphipods and (d) benthic invertebrates. The $\mathrm{MeHg}$ concentrations were calculated using equations (1) and (2) with the input data in Table 1 and the $\mathrm{MeHg} / \mathrm{Hg}^{\text {II }}$ molar ratios and BSAFs determined from $\mathrm{Hg}$ " and $\mathrm{MeHg}$ isotope tracers in the mesocosm experiment (Fig. 3), estimated loading rates of $\mathrm{Hg}^{\mathrm{II}}$ and $\mathrm{MeHg}$ from catchment runoff and the atmosphere to the Öre Estuary, sizes of sediment pools for $\mathrm{Hg}^{\mathrm{Il}}$ determined from average concentration of ambient $\mathrm{Hg}^{\prime \prime}$ from five sites within the estuary and for $\mathrm{MeHg}\left(\mathrm{X}_{\mathrm{A} 1-\mathrm{C}}\right)$ calculated as $30 \%$ of the estimated sum concentration ( $\mathrm{pmol} \mathrm{MeHg}$ per $\mathrm{g}$ d.w.) of the other five contributing sources for each scenario (described in Supplementary Information). Scenario A1 estimated present day input fluxes to the Öre Estuary (described in Supplementary Information) and a $\beta-\mathrm{HgS}(\mathrm{s}) / \mathrm{Hg}^{\mathrm{II}}-\mathrm{NOM}$ molar ratio of 70:30 in sediment as determined by $\mathrm{Hg}^{11} \mathrm{~L}_{111}$-edge EXAFS ${ }^{14}$; scenario $\mathrm{A} 2$ : $\beta-\mathrm{HgS}(\mathrm{s}) / \mathrm{Hg}^{\text {II }}-\mathrm{NOM}$ molar ratio of 30:70; scenario $\mathrm{B}$ : two times increase in catchment runoff loading compared with present day modelled for a time period of 4 months $\left(t_{0}\right)$ and the time period to replenish the $\mathrm{Hg}$ content in the $0-1.5 \mathrm{~cm}$ surface sediment ( $t_{R}=15$ years); scenario C: $27 \%$ decrease in total atmospheric $\mathrm{Hg}^{\text {II }}$ loading compared with present day (reflecting a $40 \%$ decrease in anthropogenic atmospheric $\mathrm{Hg}$ emissions assumed to constitute two-third of the total atmospheric $\mathrm{Hg}$ emissions) modelled for a time period of 4 months $\left(t_{0}\right)$ and the time period to replenish the $\mathrm{Hg}$ content in the $0-1.5 \mathrm{~cm}$ surface sediment $\left(t_{R}\right)$. 
postulated scenario if current emission controls planned and implemented in Europe and North America are implemented worldwide $^{39}$ is predicted (scenario $\mathrm{C}$ ) to only have minor shortand intermediate-term $\left(t_{0}\right.$ and $\left.t_{R}\right)$ effects on MeHg levels in biota. A significant recovery is expected only when a reduced atmospheric $\mathrm{Hg}$ loading have translated into a proportional decrease in catchment $\mathrm{MeHg}$ and $\mathrm{Hg}^{\mathrm{II}}$ runoff. The predicted time frame to reach such conditions is highly uncertain ${ }^{5,25,40}$.

\section{Discussion}

In this paper, we present the first quantitative estimates of the contribution from different geochemical $\mathrm{Hg}$ pools and sources (in situ production in sediment and input from atmosphere and terrestrial runoff) to $\mathrm{MeHg}$ levels in estuarine sediment and biota, taking into account both differentiated availability and size of the pools.

We and others have proposed that $\mathrm{Hg}$ reactivity and bioavailability are controlled by combined thermodynamic and kinetic processes ${ }^{14,19,41}$. Thermodynamic calculations using data from the mesocosm water column (Supplementary Table 1), and previous spectroscopic characterization of the $\mathrm{Hg}$ solid-phase speciation in the sediment used in this study ${ }^{14}$, show that in our experimental system reduced sulphur (organic thiols and inorganic sulphide) controls the chemical speciation of both $\mathrm{Hg}^{\mathrm{II}}$ and $\mathrm{MeHg}$. We synthesized solid/adsorbed phase Hg tracers, and added them to the sediment, as defined thermodynamically favoured chemical forms (that is, $\beta-\mathrm{HgS}(\mathrm{s}), \mathrm{Hg}(\mathrm{SR}-\mathrm{NOM})_{2}$ and MeHgSR-NOM), whereas the dissolved tracers were added to the water phase as labile complexes (dominated by $\mathrm{Hg}(\mathrm{OH})_{2}^{0}$ and $\mathrm{MeHgOH}^{0}$, respectively). The rationale for this approach is that the time required for $\mathrm{Hg}^{\mathrm{II}}$ and $\mathrm{MeHg}$ to reach equilibrium with components in the aqueous phase (including organic and inorganic particles) is relatively short (hours to maximum a few days) ${ }^{18,19}$ as compared with the slower rate (days to weeks) ${ }^{42-44}$ to form $\beta-\mathrm{HgS}(\mathrm{s})$ and adsorbed phases of $\mathrm{Hg}(\mathrm{SR}-\mathrm{NOM})_{2}$ in the sediment. As described above, the $\mathrm{Hg}^{\mathrm{II}}$ tracers added to the sediment were taken to represent sources for in situ $\mathrm{MeHg}$ formation and $\mathrm{Hg}^{\mathrm{II}}$ and $\mathrm{MeHg}$ added to the water phase were used as proxies for both terrestrial and atmospheric inputs. It should be noted that in natural environments $\mathrm{Hg}^{\mathrm{II}}$ and $\mathrm{MeHg}$ would be complexed mainly by thiol groups in terrestrial NOM in runoff, whereas the speciation of atmospherically derived $\mathrm{Hg}$ is less certain and includes dissolved inorganic $\mathrm{Hg}$ complexes and $\mathrm{Hg}$ surface complexes with organic and inorganic particles ${ }^{45}$. However, our state-of-the-art knowledge on $\mathrm{Hg}$ thermodynamics and kinetics predict that all these chemical forms would rapidly form $\mathrm{Hg}(\mathrm{SR}-\mathrm{NOM})_{2}$ and MeHgSR-NOM complexes in the oxic humic-rich brackish water of the estuary and our mesocosm systems. Previous whole-lake experiments have also indicated a rapid association of added $\mathrm{Hg}^{\mathrm{II}}$ tracers with NOM in the water column ${ }^{46}$. In contrast, the solid/adsorbed phase $\mathrm{Hg}$ tracers used in our study needed to be synthesized to thermodynamically favoured chemical forms before addition to the sediment. As illustrated in Supplementary Fig. 4, the $\mathrm{MeHg} / \mathrm{Hg}^{\mathrm{II}}$ ratio in sediment did not vary systematically throughout the experiment for any tracer, suggesting that all tracers were already equilibrated in the system at the first measurement point at day 10 .

We used the $\mathrm{MeHg} / \mathrm{Hg}^{\mathrm{II}}$ molar ratio and $\mathrm{MeHg}$ BSAF to quantify $\mathrm{MeHg}$ net formation and bioaccumulation, respectively. The calculation of relevant numbers for these parameters requires that the quantities of $\mathrm{MeHg}$ formed and bioaccumulated in the mesocosms are proportional to the amount of added tracer. This has been convincingly demonstrated in previous lake mesocosm experiments where the loading rate of a $\mathrm{Hg}^{\mathrm{II}}$ tracer to the water column was varied more than one order of magnitude 38,47 and yielded proportional amounts of formed and bioaccumulated $\mathrm{MeHg}$. We used the BSAF to quantify bioaccumulation in order to facilitate a transparent comparison of accumulation of the different tracers in all the biota species (benthic invertebrates, amphipods and plankton). Further, we could only detect $\mathrm{MeHg}$ in the water column for the $\mathrm{Me}^{199} \mathrm{Hg}_{\mathrm{wt}}$ tracer and ambient $\mathrm{MeHg}$, impeding the calculation of relevant $\mathrm{MeHg}$ Biota Accumulation Factor for the other tracers. Significant and fast removal of $\mathrm{Hg}$ tracers added to the water phase, as obtained in our systems (Supplementary Figs 2 and 3), have also been observed in previous lake littoral mesocosm studies ${ }^{47,48}$.

The approach we used, taking advantage of $\mathrm{MeHg} / \mathrm{Hg}^{\mathrm{II}}$ and $\mathrm{MeHg}$ BSAF, rely on measured quantities of $\mathrm{Hg}^{\mathrm{II}}$ and $\mathrm{MeHg}$ tracers retained and circulating in the system to quantify $\mathrm{MeHg}$ net formation and bioaccumulation. For the ecosystem scale mass balance modelling presented in Fig. 4, we have therefore estimated the fraction of $\mathrm{Hg}$ influxes retained in the modelled estuary as described in the Supplementary Discussion. Similar to previous studies ${ }^{47,49}$, losses of $\mathrm{Hg}$ tracers from the mesocosm system is expected to occur mainly as evasion of $\mathrm{Hg}^{0}$ (and potentially also of semivolatile $\mathrm{MeHg}$ complexes $^{50}$ ). Because $\mathrm{Hg}$ evasion was not monitored, we made no attempt to include that process in the model but relied on approaches using measured retained quantities of $\mathrm{Hg}$, which are inherently independent of the magnitude of $\mathrm{Hg}$ losses from the system. The limitations of our experimental setup and the assumptions and associated uncertainties underlying the model parameterization are discussed in detail in the Supplementary Discussion. Sensitivity analyses of our assumptions underpinned our major conclusions in this study: that $\mathrm{MeHg}$ in catchment runoff loading and the solid/adsorbed phase speciation of $\mathrm{Hg}^{\mathrm{II}}$ in the sediment are the major factors controlling $\mathrm{MeHg}$ content in estuarine sediment and biota.

To evaluate the validity and potential predictive power of the model, we compared the measured concentrations of ambient $\mathrm{MeHg}$ in biota collected in the mesocosm systems with modelled concentrations predicted from the $\mathrm{MeHg} / \mathrm{Hg}^{\mathrm{II}}$ molar ratio and $\mathrm{MeHg}$ BSAF data generated by the added tracers and the $\mathrm{Hg}$ input fluxes estimated for the Öre Estuary. Using scenario A1, the ambient $\mathrm{MeHg}$ concentrations in plankton, amphipods and benthic invertebrates predicted by the model (1.9, 25 and $47 \mathrm{pmolg}^{-1}$ d.w., respectively) for the Öre Estuary were in fair agreement (within a factor of 2) with the corresponding measured concentrations $\left(2.7 \pm 1.9,20 \pm 7.2\right.$ and $92 \pm 54 \mathrm{pmolg}^{-1}$ d.w. respectively) of ambient $\mathrm{MeHg}$ in our mesocosm experiments. This agreement supports the relevance and usefulness of the key data on $\mathrm{Hg}$ availability for $\mathrm{MeHg}$ formation and bioaccumulation generated in our mesocosm study by the use of solid/adsorbed and aqueous phase $\mathrm{Hg}$ tracers.

It has been desired ${ }^{25}$ to predict to what extent and within what timeframe reduced anthropogenic emissions of $\mathrm{Hg}$ could result in considerably lower $\mathrm{MeHg}$ concentration in fish. Experiments have been conducted on whole-ecosystem ${ }^{25}$ and mesocosm ${ }^{38,40,47}$ scales where the $\mathrm{MeHg}$ concentration in biota has been related to increased simulated atmospheric $\mathrm{Hg}^{\mathrm{II}}$ loading rates (by addition of isotopically enriched $\mathrm{Hg}^{\mathrm{II}}$ tracers as labile complexes, presumably dominated by $\mathrm{Hg}(\mathrm{OH})_{2}^{0}$, to the water column). These studies consistently demonstrated that the added $\mathrm{Hg}^{\mathrm{II}}$ tracers were to a substantial extent (within days to weeks depending on system scale) methylated and incorporated in the aquatic food webs. However, the contribution to $\mathrm{MeHg}$ in biota was generally smaller for the added tracer compared with ambient $\mathrm{Hg}$, suggesting that most biota $\mathrm{MeHg}$ was derived from a store of past $\mathrm{Hg}$ deposits ${ }^{40}$. Harris et al. ${ }^{25}$ found a $30-40 \%$ increase in $\mathrm{MeHg}$ in fish by increasing simulated atmospheric deposition by $120 \%$ during a 3 -year period in a whole-ecosystem 
experiment and Paterson et al. ${ }^{40}$ found a $3-10 \%$ increase in fish $\mathrm{MeHg}$ as a consequence of a $200 \%$ to $>400 \%$ increase in $\mathrm{Hg}^{\mathrm{II}}$ water loadings in a lake mesocosm experiment. Based on this it was predicted that reduced atmospheric $\mathrm{Hg}$ loadings would yield a rapid (years) initial decay in $\mathrm{MeHg}$ concentration in fish but that a full response would be delayed by a gradual export of $\mathrm{Hg}^{\mathrm{II}}$ and $\mathrm{MeHg}$ from the watershed ${ }^{25,38}$. Differences in response rate are thus expected among aquatic systems depending on the relative magnitudes of direct atmospheric $\mathrm{Hg}$ depositions to the water surface and $\mathrm{Hg}$ inputs from the watershed ${ }^{25}$. These studies have significantly advanced our understanding on $\mathrm{Hg}$ biogeochemistry, specifically on the response time of $\mathrm{MeHg}$ content in aquatic biota following reduced atmospheric $\mathrm{Hg}$ deposition. The principle experimental approach in these studies was based on comparing the fate of labile $\mathrm{Hg}^{\mathrm{II}}$ tracers added to the water phase and ambient $\mathrm{Hg}$. Utilizing our new experimental approach (combining the use of $\mathrm{Hg}^{\mathrm{II}}$ and $\mathrm{MeHg}$ isotope tracers added to both the sediment and the water phase), we can here present novel quantitative data, not included in previous studies, on formation and bioaccumulation of $\mathrm{MeHg}$ from different sediment $\mathrm{Hg}$ pools and on differences in bioaccumulation of $\mathrm{MeHg}$ loadings to the water phase versus $\mathrm{MeHg}$ formed in situ in the sediment.

One of the most striking result in our study was the considerably higher accumulation in biota of $\mathrm{MeHg}$ from the $\mathrm{Me}^{199} \mathrm{Hg}_{\text {wt }}$ tracer compared with $\mathrm{MeHg}$ formed in situ in the sediment. This was observed both for benthic organisms and plankton. These results clearly emphasize the relative importance of terrestrial $\mathrm{MeHg}$ formation and subsequent runoff for $\mathrm{MeHg}$ bioaccumulation in estuarine environments. Although land runoff causes significant direct input of $\mathrm{MeHg}$ with high availability for bioaccumulation, $\mathrm{Hg}^{\mathrm{II}}$ from atmospheric deposition that is methylated in situ forms $\mathrm{MeHg}$, which bioaccumulates to a lesser extent. It is plausible that this difference in $\mathrm{MeHg}$ availability would be less significant in aquatic systems with significant in situ $\mathrm{MeHg}$ formation in the water column ${ }^{51}$, and that the contribution to $\mathrm{MeHg}$ in biota from $\mathrm{Hg}^{\mathrm{II}}$ loadings from atmospheric depositions and land runoff would be higher in such systems. Further, our observations of high bioavailability of $\mathrm{MeHg}$ inputs to the water phase have largest implications for DOC-rich estuaries with a large watershed/water surface area ratio and/or large terrestrial $\mathrm{MeHg}$ influx rate. It can be expected that such systems will show the slowest response in $\mathrm{MeHg}$ levels in biota following reduced atmospheric $\mathrm{Hg}$ depositions.

Our study also add important data to clarify the relative importance of recent atmospherically derived $\mathrm{Hg}^{\mathrm{II}}$ and accumulated $\mathrm{Hg}^{\mathrm{II}}$ pools in sediment to $\mathrm{MeHg}$ levels in estuarine biota $^{25,38,47}$. Our results show that recent $\mathrm{Hg}^{\mathrm{II}}$ loadings to the water phase is more available for $\mathrm{MeHg}$ formation and bioaccumulation than previously deposited $\mathrm{Hg}^{\mathrm{II}}$ circulating in the ecosystem. We provide data showing that the magnitude of this discrepency, however, is largely controlled by the solid/ adsorbed phase chemical speciation of $\mathrm{Hg}^{\mathrm{II}}$ in the sediment. The net $\mathrm{MeHg}$ formation was more than ten times higher for the ${ }^{201} \mathrm{Hg}^{\mathrm{II}}-\mathrm{NOM}_{\text {sed }}$ compared with the $\beta^{-200} \mathrm{HgS}_{\text {sed }}$ tracer. This suggests that the relative contribution to biota $\mathrm{MeHg}$ levels from the accumulated sediment $\mathrm{Hg}^{\mathrm{II}}$ pool will be much lower in systems with formation of microparticulate crystalline $\beta-\mathrm{HgS}$. Such systems can thus be expected to exhibit a significantly stronger initial response in biota $\mathrm{MeHg}$ levels following reduced atmospheric $\mathrm{Hg}^{\mathrm{II}}$ deposition compared with systems dominated by $\mathrm{Hg}(\mathrm{SR}-\mathrm{NOM})_{2}$ complex formation in the sediment. Orihel et al. ${ }^{48}$, using an experimental approach where labile $\mathrm{Hg}^{\mathrm{II}}$ tracers were added to the water column of a lake littoral mesocosm system in two consecutive years, reported a higher $\mathrm{MeHg}$ concentration in plankton from the newly added tracer compared with the tracer aged for 1 year in the system.
However, in a similar 2-year mesocosm $\mathrm{Hg}$ tracer addition experiment, Paterson et al. ${ }^{40}$ observed the opposite trend. In view of the less available $\mathrm{Hg}^{\mathrm{II}}$ pertaining to adsorbed and solid phases in sediments reported in our study, the lower availability of $\mathrm{Hg}^{\mathrm{II}}$ tracers after 1 year of aging reported by Orihel et al. could be interpreted as an effect of $\mathrm{HgS}(\mathrm{s})$ and $\mathrm{Hg}(\mathrm{SR}-\mathrm{NOM})_{2}$ formation in sediments.

Enhanced rates of $\mathrm{MeHg}$ formation have been observed in bacteria culture experiments amended with nanoparticulate compared with microparticulate $\mathrm{HgS}(\mathrm{s})^{9,41}$. The underlying mechanisms for this discrepancy, as well as the quantitative importance of nanoparticulate $\mathrm{HgS}(\mathrm{s})$ in natural sediment, however, remain unclear. If the observed differences in $\mathrm{MeHg}$ formation rate are due to higher solubility and/or dissolution rate of nanoparticulate $\mathrm{HgS}(\mathrm{s})$, it, if present in the sediment, may exhibit a $\mathrm{MeHg} / \mathrm{Hg}^{\mathrm{II}}$ molar ratio in-between the observed ratios for the ${ }^{201} \mathrm{Hg}^{\mathrm{II}}-\mathrm{NOM}_{\text {sed }}$ and $\beta_{-}{ }^{201} \mathrm{HgS}_{\text {sed }}$ tracers used in our study.

The recently UNEP negotiated Minamata treaty to limit anthropogenic $\mathrm{Hg}$ emissions ${ }^{52}$ has further spurred questions on how fast ecosystems may recover following reduced atmospheric $\mathrm{Hg}$ emissions and if other changes (for example, climate) in the systems ${ }^{53}$ can counteract or amplify the recovery processes. Such predictions have been hampered by a limited understanding on how different geochemical pools/sources of $\mathrm{Hg}$ in the environment contribute to $\mathrm{MeHg}$ in biota. Pool-specific contributions must be established to understand in detail the $\mathrm{Hg}$ biogeochemical cycle and for accurate predictions on the outcome of reduced anthropogenic $\mathrm{Hg}$ emissions and potential impacts on $\mathrm{Hg}$ levels in biota following climate change scenarios and anthropogenic land use. Traditional $\mathrm{Hg}$ mass balance models may not accurately address this issue as quantitative data on the different $\mathrm{Hg}$ pools' availability to $\mathrm{MeHg}$ formation and bioaccumulation have been lacking. Our findings thus have farreaching implications for central scientific questions on $\mathrm{Hg}$ biogeochemistry as well as applied aspects of environmental policy and should be considered in future biogeochemical $\mathrm{Hg}$ cycling models at regional and global scales.

\section{Methods}

Site description and sampling. The Öre Estuary is located at the Swedish east coast and connects to the Bothnian Sea. The estuary covers an area of $50 \mathrm{~km}^{2}$ and has a total volume of $10^{9} \mathrm{~m}^{3}$ and average depth of $16.4 \mathrm{~m}$. Öre River is the main source of suspended particles to the estuary and the bottoms are dominated by sediment with a discontinued deposition of fine grained particles (so called

transportation bottoms). Intact sediment cores $\left(\sim 0.2 \times 0.63 \mathrm{~m}^{2} \varnothing\right)$ were manually collected by divers (coordinates: $63^{\circ} 33.905^{\prime} \mathrm{N}, 19^{\circ} 50.898^{\prime} \mathrm{E}$ ) at water depth of 5-7 $\mathrm{m}$ using custom-made sampling devices consisting of HDPE (same material as the mesocosm systems described below) cylinders with detachable bottom and lid. Each cylinder was immersed into undisturbed sediment and then cleared from surrounding sediment to allow inserting the bottom plate through a notch in the cylinder wall. The lid was then placed on a rim a few centimetre above the sediment surface. The cores were lifted onto a research vessel and placed in barrels filled with brackish water to avoid leakage and direct contact with air. Sediment cores were then stored dark at $15^{\circ} \mathrm{C}$ for up to 7 days. The average sediment density and dry weight were $1.18 \pm 0.03 \mathrm{~g} \mathrm{~cm}^{-3}$ and $32 \pm 4.1 \%$, respectively. Unfiltered seawater was collected (salinity of 5 Practical Salinity Units (PSU)) using a peristaltic pump system connected to parallel pipes with the inlet located $800 \mathrm{~m}$ from land (in the Öre Estuary) and at water depths of 2 and $8 \mathrm{~m}$. All mesocosms were filled with water in parallel to assure similar distribution of, for example, planktonic organism communities.

Mesocosm system preparation and isotope tracer additions. The mesocosm facility is located at the Umeå Marine Sciences Centre and consists of totally 12 double-mantled HDPE tubes $\left(5 \times 0.74 \mathrm{~m}^{2} \varnothing\right)$ that are temperature controlled in sections via an outer layer of glycol. $150 \mathrm{~W}$ metal halogen lamps (MASTERColour CDM-T 150W/942 G12 1CT) were used as light source with a light/dark cycle of 12:12 h. Temperature of the water column was controlled in three sections with a set temperature of $14^{\circ} \mathrm{C}$ in the top layer $\left(0.1-1.4 \mathrm{~m}\right.$ depth) and $16^{\circ} \mathrm{C}$ in the middle layer (1.85-3.15 $\mathrm{m}$ depth) creating a mixing by thermal convection in the upper part of the water column and a thermocline at $\sim 3.2 \mathrm{~m}$ between the middle and lowest section (Supplementary Fig. 5). The lowest section (3.6-4.9 m depth) was set 
to $10^{\circ} \mathrm{C}$. Separate mesocosm experiments showed complete mixing of the upper part of the water column within a few hours. Nitrate $\left(\mathrm{NO}_{3}^{-}\right)$, phosphate $\left(\mathrm{PO}_{4}^{3-}\right)$ and ammonium $\left(\mathrm{NH}_{4}^{+}\right)$solutions were prepared from salts $\left(\mathrm{NaNO}_{3}\right.$,

$\mathrm{NaH}_{2} \mathrm{PO}_{4} \times \mathrm{H}_{2} \mathrm{O}$ and $\mathrm{NH}_{4} \mathrm{Cl}$ ) and added to the mesocosm water phase at amounts giving a concentration increase corresponding to $10 \%$ (days $1,3,8,12$ ) or $5 \%$ (days 16, 18 (only $\mathrm{PO}_{4}^{3-}$ and $\mathrm{NH}_{4}^{+}$), 22, 25 and 32) of the concentration typical for winter conditions in the Bothnian Sea $\left(10 \mu \mathrm{M} \mathrm{NO}_{3}^{-}, 0.77 \mu \mathrm{M} \mathrm{PO}_{4}^{3-}, 1.8 \mu \mathrm{M}\right.$ $\left.\mathrm{NH}_{4}^{+}\right)^{54}$. The date for the first nutrient addition is referred to as day 1 and the experiment then continued for 57 days. The mesocosms were regularly filled up with fresh, tempered, brackish water $\left(\sim 21 \mathrm{day}^{-1}\right)$ to compensate for losses of water from sampling and evaporation and maintain a constant water volume of $\sim 1,9501$.

$\mathrm{Hg}$ II enriched in ${ }^{196} \mathrm{Hg}(50 \%),{ }^{198} \mathrm{Hg}(92.78 \%),{ }^{199} \mathrm{Hg}(91.95 \%),{ }^{200} \mathrm{Hg}$ (96.41\%), ${ }^{201} \mathrm{Hg}(98.11 \%)$ or ${ }^{204} \mathrm{Hg}(98.11 \%)$ (as $\mathrm{HgO}$ or $\mathrm{HgCl}_{2}$ ) were purchased from Oak Ridge National Laboratory. Isotopically enriched $\mathrm{MeH}^{55}$ and $\beta$ ${ }^{200} \mathrm{HgS}(\mathrm{s}){ }^{14}$ were synthesized as described elsewhere. The ${ }^{201} \mathrm{Hg}^{\mathrm{II}}$-NOM and $\mathrm{Me}^{198} \mathrm{Hg}$-NOM tracers were prepared according to Jonsson et al. ${ }^{14}$ by adding ${ }^{201} \mathrm{Hg}(\mathrm{aq})$ or $\mathrm{Me}^{198} \mathrm{Hg}(\mathrm{aq})$ to a Milli-Q (MQ; resistivity $>18.2 \mathrm{M} \Omega \mathrm{cm}$ ) water suspension of a freeze-dried and ball-milled, homogenized peat soil previously characterized by Skyllberg and Drott ${ }^{56}$. The estimated $\mathrm{Hg} / \mathrm{RSH}$ molar ratio was kept in the range previously demonstrated to give $1: 2 \mathrm{Hg}^{\mathrm{II}}: \mathrm{RSH}$ and 1:1 MeHg:RSH complex stoichiometry for binding of $\mathrm{Hg}$ to this peat soi ${ }^{57}$. A slurry mixture of $\beta^{200} \mathrm{HgS}(\mathrm{s}),{ }^{201} \mathrm{Hg}^{\mathrm{II}}-\mathrm{NOM}$ and $\mathrm{Me}^{198} \mathrm{Hg}-\mathrm{NOM}$ was prepared within $1 \mathrm{~h}$ before injected into the intact sediment cores using an electronic 12-channel pipette (VWR, 10-200 $\mu \mathrm{l}$ sample aliquots). Amounts of $12 \times 100 \mu \mathrm{l}$ of the slurry were withdrawn and injected $\sim 0.5 \mathrm{~cm}$ below the sediment surface in $10 \mu \mathrm{l}$ portions with $1 \mathrm{~cm} x$ axis distance (controlled using a custom made grid system) and $0.8 \mathrm{~cm} y$ axis distance between pipette tips, which gave 1.13 injections per $\mathrm{cm}^{2}$ (final concentrations are given in Supplementary Table 2). In total, 3,264 injections were made for two of the mesocosms (denoted M2 and M3) covering $92 \%$ of the sediment surface. Owing to a disturbed surface in the outer part of the third sediment core (mesocosm denoted M1), instead 2,946 injections were made covering $83 \%$ of the surface area. Sediment not covered by tracer additions was located in the outer part of the sediment cores and no sediment sub-samples were taken from this part during the experiment. Sediment cores were spiked and immersed into water-filled mesocosms with the lid removed after placement of the sediment cylinders on bottom of the mesocosm tubes to protect the sediment surface during placement. ${ }^{204} \mathrm{Hg}^{\mathrm{II}}$ wt and $\mathrm{Me}^{199} \mathrm{Hg}_{\mathrm{wt}}$ were added day 2 of the experiment to the upper part of the water column (above the thermocline) $20 \mathrm{~min}$ after light was turned off, that is, at the beginning of a 12 -h dark cycle to minimize evasion losses ${ }^{49}$

Sampling and analysis. Water and sediment were sampled once a week from the mesocosms for the determination of primary and bacterial production rates (Supplementary Fig. 6), DOC, humic matter, light transmittance and $\mathrm{O}_{2}$ saturation (Supplementary Table 3 ) and $\mathrm{Hg}^{\mathrm{II}}$ methylation and $\mathrm{MeHg}$ demethylation rate constants $\left(k_{\mathrm{m}}\right.$ and $\left.k_{\mathrm{d}}\left(\mathrm{d}^{-1}\right)\right)$, and concentrations of nutrients, Chl $\alpha$, total Hg (tot$\mathrm{Hg}$ ) and $\mathrm{MeHg}$ in water as well as determination of $k_{\mathrm{m}}$ and $k_{\mathrm{d}}$, dry weight and the concentrations of $\mathrm{MeHg}$ and tot-Hg in sediment. Sediment sub-cores were sampled from the mesocosm sediments during the experiment using a custom-made sampler designed for the mesocosms (Supplementary Fig. 7). Depth profiles of $\mathrm{H}_{2} \mathrm{~S}$, $\mathrm{O}_{2}$, redox and $\mathrm{pH}$ were also measured in sediment samples using microelectrodes (Unisense). Sedimented material was collected for determination of $\delta^{13} \mathrm{C}, \delta^{15} \mathrm{~N}, \mathrm{C}$ (\%) and $\mathrm{N}(\%)$ and the concentrations of $\mathrm{MeHg}$ and tot-Hg. Seston size fractions and benthic organisms were collected at the end of the experiment for determination of $\delta^{13} \mathrm{C}, \delta^{15} \mathrm{~N}, \mathrm{C}(\%)$ and $\mathrm{N}(\%)$ and concentration of $\mathrm{MeHg}$ and tot- $\mathrm{Hg}$ Pressure, turbidity and $\mathrm{O}_{2}$ were measured in situ in the water column using a Seaguard CTD with attached microelectrode sensors (Unisence) and light penetration using a Spherical Quantum Sensor (LI-COR, 193-SA and LI-COR 1400 unit). Details of sampling and analysis are provided in the supporting information. Briefly, the concentratons of tot- $\mathrm{Hg}$ and $\mathrm{MeHg}$ in water, sediment and biota were determined using ${ }^{196} \mathrm{Hg}^{\mathrm{II}}$ or $\mathrm{Me}^{196} \mathrm{Hg}$ as internal standard for isotope dilution analysis, matrix and analyte-specific extraction and preconcentraiton techniques followed by inductively coupled plasma mass spectrometry (ICPMS) analysis for tot-Hg and Gas Chromatography-ICPMS analysis for MeHg. Concentrations of tot- $\mathrm{Hg}$ and $\mathrm{MeHg}$ for ambient $\mathrm{Hg}$ and tracers were then calculated from mass-bias corrected signals using signal deconvolution ${ }^{58}$. The determined Hg parameters and concentrations are given in Supplementary Tables 4-8.

Detection limit and quality control for $\mathbf{H g}$ determinations. With the experimental setup in this study, the signals for individual $\mathrm{Hg}$ isotope tracers in the ICPMS analyses are detected superimposed on a 'background' of ambient $\mathrm{Hg}$ and contributions from minor isotopes of the other tracers present in the sample. The limit of detection (LOD) can therefore not be assessed by common approaches with blank samples. Indeed, the LOD for tot- $\mathrm{Hg}$ and $\mathrm{MeHg}$ determinations will vary among individual tracers and samples. We defined LOD for $\mathrm{Hg}$ tracers as the $\mathrm{Hg}$ amount giving a $4.8 \%$ signal contribution to the total measured signal intensity at the specific isotope mass. This factor was determined based on typical expanded uncertainties in measured signal intensities, and thus an individual LOD was calculated for each isotope tracer and sample.
Certified reference materials were analysed with every sample batch for the determination of $\mathrm{MeHg}$ and tot-Hg concentrations in sediment and biota. The obtained results (average $\pm \mathrm{CI}, P=0.05)$ were $81 \pm 2$ ng MeHg per g d.w. $(n=33)$ for $\mathrm{MeHg}$ in sediment (ERM-CC580, certified value $75 \pm 4 \mathrm{ng} \mathrm{MeHg}$ per $\mathrm{g}$ d.w.), $683 \pm 39 \mathrm{ng} \mathrm{Hg}$ per g d.w. $(n=4)$ for $\mathrm{MeHg}$ in biota (DOLT-2, certified value $693 \pm 53 \mathrm{ng} \mathrm{Hg}$ per g d.w.), $102 \pm 6 \mathrm{ng} \mathrm{Hg}$ per g d.w. $(n=6)$ for tot-Hg in sediment (Mess-3, certified value $91 \pm 9 \mathrm{ng} \mathrm{Hg}$ per g d.w.) and $2.24 \pm 0.08 \mu \mathrm{g} \mathrm{Hg}$ per g d.w. $(n=8)$ for tot-Hg in biota (DOLT-2, certified value $2.14 \pm 0.28 \mu \mathrm{g} \mathrm{Hg}$ per g d.w.). Well-established standard procedures were used for all other determined parameters.

Hg mass balance model. We calculated the concentration of ambient $\mathrm{MeHg}$ in sediment and biota using equations (1) and (2), respectively. Scenario A1 and A2 were based on estimated present day catchment runoff and atmospheric deposition inputs of $\mathrm{Hg}^{\mathrm{II}}$ and $\mathrm{MeHg}$ to the Öre Estuary. Amounts of accumulated $\mathrm{Hg}^{\mathrm{II}}$ in the sediment present as $\beta$-HgS(s) and $\mathrm{Hg}^{\mathrm{II}}$-NOM, respectively, were calculated from an average concentration of ambient tot- $\mathrm{Hg}\left(280 \mathrm{pmol} \mathrm{g}^{-1}\right.$ d.w.) for five sampling sites within the estuary estimated from data reported by Lambertsson and Nils$\operatorname{son}^{27}$, and a $\beta-\mathrm{HgS}(\mathrm{s}) / \mathrm{Hg}^{\mathrm{II}}$-NOM molar ratio of 70:30 in scenario A1 (as determined previously for sediments from the same sampling location using $\mathrm{L}_{\mathrm{III}}{ }^{-}$ edge $\mathrm{Hg}-\mathrm{EXAFS}^{14}$ ) and 30:70 in scenario A2. In scenario B, we modelled a two times increase in catchment runoff loading of $\mathrm{Hg}^{\mathrm{II}}$ and $\mathrm{MeHg}$, and in scenario $\mathrm{C}$, we modelled a $40 \%$ reduction in anthropogenic atmospheric emission of $\mathrm{Hg}$ (as predicted by Pacyna et al. ${ }^{39,59}$ for 2020 if emission controls planned and implemented in Europe and North America are implemented worldwide) resulting in a net decrease of total atmospheric $\mathrm{Hg}^{\mathrm{II}}$ deposition of $27 \%$ (assuming that $67 \%$ of the total amount of atmospheric $\mathrm{Hg}$ emissions are anthropogenic $\left.{ }^{60}\right)$. The total $\mathrm{MeHg}$ concentration in sediment $\left([\mathrm{MeHg}]_{\text {sed; }}\right.$ pmol g ${ }^{-1}$ d.w. in $\left.0-1.5 \mathrm{~cm}\right)$ and specific contributions from different geochemical $\mathrm{Hg}$ pools were calculated using $\mathrm{MeHg} / \mathrm{Hg}^{\mathrm{II}}$ molar ratios determined from isotope-enriched $\mathrm{Hg}^{\mathrm{II}}$ and $\mathrm{MeHg}$ tracers in the mesocosm experiment, estimated loading rates of $\mathrm{Hg}^{\mathrm{II}}$ and $\mathrm{MeHg}$ from catchment runoff and atmospheric deposition (mol per 4 months; Table 1) and $\mathrm{Hg}^{\mathrm{II}}$ and $\mathrm{MeHg}$ stored in the top $1.5 \mathrm{~cm}$ of the sediment as $\beta-\mathrm{HgS}(\mathrm{s})$ and $\mathrm{Hg}^{\mathrm{II}}$-NOM (mol). MeHg stored in sediment and not readily available for demethylation was calculated using a factor, $F_{[\mathrm{MeHg}] \text { sediment, }}$ set to 0.30 of the sum of the other contributing sources. The absolute amounts of $\mathrm{MeHg}$ ( $\mathrm{mol}$ in $0-1.5 \mathrm{~cm})$ were recalculated to a concentration $\left(\mathrm{pmolg}^{-1}\right.$ d.w. in $\left.0-1.5 \mathrm{~cm}\right)$ using a conversion factor $C$ of $3.53 \times 10^{12} \mathrm{~g}^{-1}$ d.w. $\left(C=\left(\right.\right.$ density $_{\text {sed }}(\mathrm{g}$ w.w. $\left.\mathrm{cm}^{-3}\right) \times$ d.w./wet weight (w.w.) ratio $\times$ sediment depth $(\mathrm{cm}) \times$ estuary area $\left.\left.\left(\mathrm{cm}^{2}\right)\right)^{-1} \times 10^{12}\right)$.

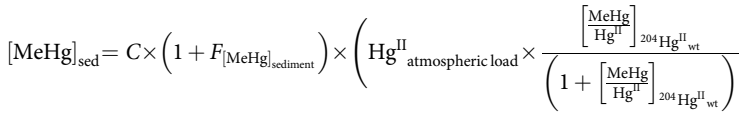

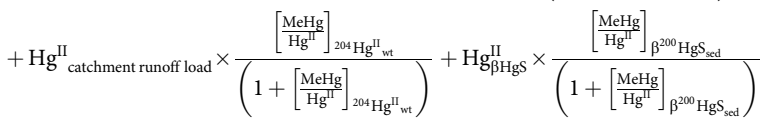

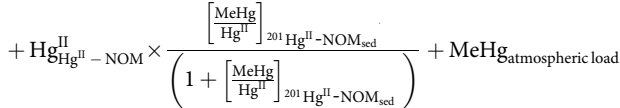

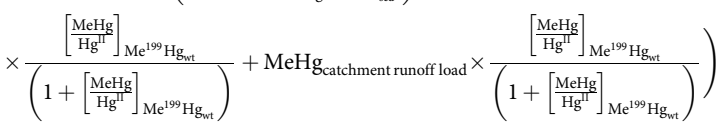

The total MeHg concentration (pmolg ${ }^{-1}$ d.w.) in biota ([MeHg $]_{\text {biota }}$ ) and specific contributions from different geochemical $\mathrm{Hg}$ pools were calculated using the predicted concentration of $\mathrm{MeHg}\left(\mathrm{pmolg}^{-1}\right.$ d.w.) in the sediment $(0-1.5 \mathrm{~cm})$ from each geochemical $\mathrm{Hg}$ pool calculated by equation (1) (for example, as

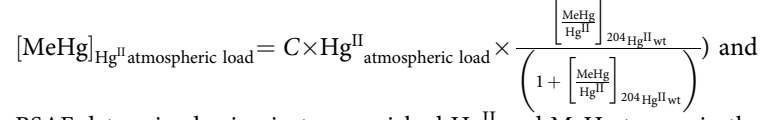

BSAF determined using isotope enriched $\mathrm{Hg}^{\mathrm{II}}$ and $\mathrm{MeHg}$ tracers in the mesocosm experiment, where, for example, $\mathrm{BSAF}_{204} \mathrm{Hg}_{\mathrm{gt}}{ }_{\mathrm{wt}}$ denotes $\mathrm{BSAF}$ for $\mathrm{MeHg}$ formed from the ${ }^{204} \mathrm{Hg}^{\mathrm{II}}{ }_{\text {wt }}$ tracer.

$$
\begin{aligned}
& {[\mathrm{MeHg}]_{\text {biota }}=[\mathrm{MeHg}]_{\mathrm{Hg}^{\mathrm{II}} \text { atmospheric load }} \times \mathrm{BSAF}^{204} \mathrm{Hg}_{\mathrm{wt}}^{\mathrm{II}}+[\mathrm{MeHg}]_{\mathrm{Hg}^{\mathrm{II}} \text { catchment runoff load }} \times} \\
& \mathrm{BSAF}_{204} \mathrm{Hg}_{\mathrm{wt}}+\left([\mathrm{MeHg}]_{\beta \mathrm{HgS}}+[\mathrm{MeHg}]_{\mathrm{Hg}^{\mathrm{II}}-\mathrm{NOM}} \times \mathrm{BSAF}_{\text {average }\left(\beta^{200} \mathrm{HgS}_{\text {sed }}{ }^{201} \mathrm{Hg}^{\mathrm{II}}-\mathrm{NOM}_{\text {sed }}\right)}\right. \\
& +[\mathrm{MeHg}]_{\mathrm{MeHg} \text { atmospheric load }} \times \mathrm{BSAF}_{\mathrm{Me}^{199} \mathrm{Hg}_{\mathrm{wt}}}+[\mathrm{MeHg}]_{\mathrm{MeHg} \text { catchment runoff load }} \times \\
& \mathrm{BSAF}_{\mathrm{Me}^{199} \mathrm{Hg}_{\mathrm{wt}}}+[\mathrm{MeHg}]_{\mathrm{MeHg}-\text { Stored }} \times \mathrm{BSAF}_{\mathrm{Me}^{198} \mathrm{Hg}-\mathrm{NOM}_{\text {sed }}}
\end{aligned}
$$

Statistical data treatment. All data are presented as average \pm CI $(p=0.05)$. Differences in $\mathrm{MeHg} / \mathrm{Hg}^{\mathrm{II}}$ molar ratios and $\mathrm{MeHg}$ BSAFs of isotopically enriched tracers and ambient $\mathrm{Hg}$ were tested by one-way analysis of variance (Supplementary Tables 4 and 5, with their underlying raw data given in 
Supplementary Tables 6-8). If $\alpha<0.05$ the null-hypothesis (no difference among treatments) was rejected and Tukey's post hoc analysis $(p=0.05)$ was used to identifying groups statistically differing. All calculations were conducted using EXCEL 2010 (Microsoft).

\section{References}

1. Mason, R. P. et al. Mercury biogeochemical cycling in the ocean and policy implications. Environ. Res. 119, 101-117 (2012).

2. Mason, R. P. et al. Mercury in the Chesapeake Bay. Mar. Chem. 65, 77-96 (1999).

3. Benoit, J. M., Gilmour, C. C., Mason, R. P. \& Heyes, A. Sulfide controls on mercury speciation and bioavailability to methylating bacteria in sediment pore waters. Environ. Sci. Technol. 33, 951-957 (1999).

4. Fleming, E. J., Mack, E. E., Green, P. G. \& Nelson, D. C. Mercury methylation from unexpected sources: molybdate-inhibited freshwater sediments and an iron-reducing bacterium. Appl. Environ. Microb. 72, 457-464 (2006).

5. Munthe, J. et al. Recovery of mercury-contaminated fisheries. Ambio 36, 33-44 (2007).

6. Compeau, G. C. \& Bartha, R. Sulfate-reducing bacteria-principal methylators of mercury in anoxic estuarine sediment. Appl. Environ. Microb. 50, 498-502 (1985)

7. Parks, J. M. et al. The genetic basis for bacterial mercury methylation. Science 339, 1332-1335 (2013).

8. Gilmour, C. C. et al. Mercury methylation by novel microorganisms from new environments. Environ. Sci. Technol. 47, 11810-11820 (2013).

9. Zhang, T. et al. Methylation of mercury by bacteria exposed to dissolved, nanoparticulate, and microparticulate mercuric sulfides. Environ. Sci. Technol. 46, 6950-6958 (2012).

10. Drott, A., Bjorn, E., Bouchet, S. \& Skyllberg, U. Refining thermodynamic constants for mercury(II)-sulfides in equilibrium with metacinnabar at sub-micromolar aqueous sulfide concentrations. Environ. Sci. Technol. 47, 4197-4203 (2013)

11. Schaefer, J. K. \& Morel, F. M. M. High methylation rates of mercury bound to cysteine by Geobacter sulfurreducens. Nat. Geosci. 2, 123-126 (2009).

12. Schaefer, J. K. et al. Active transport, substrate specificity, and methylation of $\mathrm{Hg}$ (II) in anaerobic bacteria. Proc. Natl Acad. Sci. USA 108, 8714-8719 (2011).

13. Fitzgerald, W. F., Lamborg, C. H. \& Hammerschmidt, C. R. Marine biogeochemical cycling of mercury. Chem. Rev. 107, 641-662 (2007).

14. Jonsson, S. et al. Mercury methylation rates for geochemically relevant $\mathrm{HgII}$ species in sediments. Environ. Sci. Technol. 46, 11653-11659 (2012).

15. Ndu, U., Mason, R. P., Zhang, H., Lin, S. J. \& Visscher, P. T. effect of inorganic and organic ligands on the bioavailability of methylmercury as determined by using a mer-lux bioreporter. Appl. Environ. Microb. 78, 7276-7282 (2012)

16. Pickhardt, P. C. \& Fisher, N. S. Accumulation of inorganic and methylmercury by freshwater phytoplankton in two contrasting water bodies. Environ. Sci. Technol. 41, 125-131 (2007).

17. Leaner, J. J. \& Mason, R. P. Factors controlling the bioavailability of ingested methylmercury to channel catfish and Atlantic sturgeon. Environ. Sci. Technol. 36, 5124-5129 (2002).

18. Hintelmann, H. \& Harris, R. Application of multiple stable mercury isotopes to determine the adsorption and desorption dynamics of $\mathrm{Hg}$ (II) and $\mathrm{MeHg}$ to sediments. Mar. Chem. 90, 165-173 (2004).

19. Miller, C. L., Southworth, G., Brooks, S., Liang, L. Y. \& Gu, B. H. Kinetic controls on the complexation between mercury and dissolved organic matter in a contaminated environment. Environ. Sci. Technol. 43, 8548-8553 (2009).

20. Skyllberg, U. Competition among thiols and inorganic sulfides and polysulfides for $\mathrm{Hg}$ and $\mathrm{MeHg}$ in wetland soils and sediments under suboxic conditions: Illumination of controversies and implications for $\mathrm{MeHg}$ net production. J. Geophys. Res-Biogeo. 113, G00C03 (2008).

21. Chadwick, S. P., Babiarz, C. L., Hurley, J. P. \& Armstrong, D. E. Importance of hypolimnetic cycling in aging of 'new' mercury in a northern temperate lake. Sci. Total Environ. 448, 176-188 (2013).

22. Alling, V., Humborg, C., Morth, C. M., Rahm, L. \& Pollehne, F. Tracing terrestrial organic matter by delta(34)S and delta(13)C signatures in a subarctic estuary. Limnol. Oceanogr. 53, 2594-2602 (2008).

23. Stockdale, A., Davison, W. \& Zhang, H. Micro-scale biogeochemical heterogeneity in sediments: a review of available technology and observed evidence. Earth-Sci. Rev. 92, 81-97 (2009).

24. Hintelmann, H., Keppel-Jones, K. \& Evans, R. D. Constants of mercury methylation and demethylation rates in sediments and comparison of tracer and ambient mercury availability. Environ. Toxicol. Chem. 19, 2204-2211 (2000).

25. Harris, R. C. et al. Whole-ecosystem study shows rapid fish-mercury response to changes in mercury deposition. Proc. Natl Acad. Sci. USA 104, 16586-16591 (2007).
26. Hines, N. A., Brezonik, P. L. \& Engstrom, D. R. Sediment and porewater profiles and fluxes of mercury and methylmercury in a small seepage lake in northern Minnesota. Environ. Sci. Technol. 38, 6610-6617 (2004).

27. Lambertsson, L. \& Nilsson, M. Organic material: The primary control on mercury methylation and ambient methyl mercury concentrations in estuarine sediments. Environ. Sci. Technol. 40, 1822-1829 (2006).

28. Lambertsson, L., Lundberg, E., Nilsson, M. \& Frech, W. Applications of enriched stable isotope tracers in combination with isotope dilution GC-ICP-MS to study mercury species transformation in sea sediments during in situ ethylation and determination. J. Anal. At. Spectrom. 16, 1296-1301 (2001).

29. Castelle, S. et al. 50-year record and solid state speciation of mercury in natural and contaminated reservoir sediment. Appl. Geochem. 22, 1359-1370 (2007).

30. Marvin-DiPasquale, M. et al. Methyl-mercury degradation pathways: a comparison among three mercury-impacted ecosystems. Environ. Sci. Technol. 34, 4908-4916 (2000).

31. Lawrence, A. L. \& Mason, R. P. Factors controlling the bioaccumulation of mercury and methylmercury by the estuarine amphipod Leptocheirus plumulosus. Environ. Pollut. 111, 217-231 (2001).

32. Eagles-Smith, C. A., Suchanek, T. H., Colwell, A. E. \& Anderson, N. L. Mercury trophic transfer in a eutrophic lake: the importance of habitat-specific foraging. Ecol. Appl. 18, A196-A212 (2008).

33. Akerblom, S., Nilsson, M., Yu, J., Ranneby, B. \& Johansson, K. Temporal change estimation of mercury concentrations in northern pike (Esox lucius L.) in Swedish lakes. Chemosphere 86, 439-445 (2012).

34. Monson, B. A. Trend reversal of mercury concentrations in piscivorous fish from Minnesota Lakes: 1982-2006. Environ. Sci. Technol 43, 1750-1755 (2009).

35. Fisher, J. A. et al. Riverine source of Arctic Ocean mercury inferred from atmospheric observations. Nat. Geosci. 5, 499-504 (2012).

36. Bishop, K. et al. The effects of forestry on hg bioaccumulation in nemoral/ boreal waters and recommendations for good silvicultural practice. Ambio 38, 373-380 (2009)

37. Tjerngren, I., Meili, M., Bjorn, E. \& Skyllberg, U. Eight Boreal Wetlands as sources and sinks for methyl mercury in relation to soil acidity, C/N Ratio, and small-scale flooding. Environ. Sci. Technol. 46, 8052-8060 (2012).

38. Orihel, D. M., Paterson, M. J., Blanchfield, P. J., Bodaly, R. A. \& Hintelmann, H. Experimental evidence of a linear relationship between inorganic mercury loading and methylmercury accumulation by aquatic biota. Environ. Sci. Technol. 41, 4952-4958 (2007).

39. UNEP. The Global Atmosperic Mercury Assessment: Sources, Emissions and Transport (UNEP (2008).

40. Paterson, M. J. et al. Bioaccumulation of newly deposited mercury by fish and invertebrates: an enclosure study using stable mercury isotopes. Can. J. Fish. Aquat. Sci. 63, 2213-2224 (2006).

41. Hsu-Kim, H., Kucharzyk, K. H., Zhang, T. \& Deshusses, M. A. Mechanisms regulating mercury bioavailability for methylating microorganisms in the aquatic environment: a critical review. Environ. Sci. Technol. 47, 2441-2456 (2013).

42. Skyllberg, U., Xia, K., Bloom, P. R., Nater, E. A. \& Bleam, W. F. Binding of mercury(II) to reduced sulfur in soil organic matter along upland-peat soil transects. J. Environ. Qual. 29, 855-865 (2000).

43. Slowey, A. J. Rate of formation and dissolution of mercury sulfide nanoparticles: the dual role of natural organic matter. Geochim. Cosmochim. Acta 74, 4693-4708 (2010).

44. Liao, L., Selim, H. M. \& DeLaune, R. D. Mercury Adsorption-Desorption and Transport in Soils. J. Environ. Qual. 38, 1608-1616 (2009).

45. Amos, H. M. et al. Gas-particle partitioning of atmospheric $\mathrm{Hg}$ (II) and its effect on global mercury deposition. Atmos. Chem. Phys. 12, 591-603 (2012).

46. Chadwick, S. P., Babiarz, C. L., Hurley, J. P. \& Armstrong, D. E. Influences of iron, manganese, and dissolved organic carbon on the hypolimnetic cycling of amended mercury. Sci. Total Environ. 368, 177-188 (2006).

47. Orihel, D. M. et al. Effect of loading rate on the fate of mercury in littoral mesocosms. Environ. Sci. Technol. 40, 5992-6000 (2006).

48. Orihel, D. M. et al. Temporal changes in the distribution, methylation, and bioaccumulation of newly deposited mercury in an aquatic ecosystem. Environ. Pollut. 154, 77-88 (2008)

49. Amyot, M. et al. Formation and evasion of dissolved gaseous mercury in large enclosures amended with ( $\mathrm{HgCl} 2)-\mathrm{Hg}-200$. Atmos. Environ. 38, 4279-4289 (2004).

50. Jonsson, S., Skyllberg, U. \& Bjorn, E. Substantial emission of gaseous monomethylmercury from contaminated water-sediment microcosms. Environ. Sci. Technol. 44, 278-283 (2010).

51. Eckley, C. S. \& Hintelmann, H. Determination of mercury methylation potentials in the water column of lakes across Canada. Sci. Total Environ. 368, 111-125 (2006).

52. UNEP. Minamata Convention on Mercury (UNEP, 2013). 
53. Krabbenhoft, D. P. \& Sunderland, E. M. Global change and mercury. Science 341, 1457-1458 (2013).

54. Andersson, A., Hajdu, S., Haecky, P., Kuparinen, J. \& Wikner, J. Succession and growth limitation of phytoplankton in the Gulf of Bothnia (Baltic Sea). Mar. Biol. 126, 791-801 (1996).

55. Snell, J. P., Stewart, I. I., Sturgeon, R. E. \& Frech, W. Species specific isotope dilution calibration for determination of mercury species by gas chromatography coupled to inductively coupled plasma- or furnace atomisation plasma ionisation-mass spectrometry. J. Anal. At. Spectrom. 15, 1540-1545 (2000).

56. Skyllberg, U. \& Drott, A. Competition between disordered iron sulfide and natural organic matter associated thiols for mercury(II)-An EXAFS study. Environ. Sci. Technol. 44, 1254-1259 (2010).

57. Skyllberg, U., Bloom, P. R., Qian, J., Lin, C. M. \& Bleam, W. F. Complexation of mercury(II) in soil organic matter: EXAFS evidence for linear twocoordination with reduced sulfur groups. Environ. Sci. Technol. 40, 4174-4180 (2006).

58. Qvarnstrom, J. \& Frech, W. Mercury species transformations during sample pre-treatment of biological tissues studied by HPLC-ICP-MS. J. Anal. At. Spectrom. 17, 1486-1491 (2002).

59. Pacyna, E. G. et al. Global emission of mercury to the atmosphere from anthropogenic sources in 2005 and projections to 2020. Atmos. Environ. 44, 2487-2499 (2010).

60. Selin, N. E. et al. Global 3-D land-ocean-atmosphere model for mercury: present-day versus preindustrial cycles and anthropogenic enrichment factors for deposition. Glob. Biogeochem. Cycle 22, GB3099 (2008).

\section{Acknowledgements}

This work was supported by the Swedish Research Council (grant 2008-4363), the Kempe Foundation (grants SMK-2942, SMK-2745, JCK-2413), Umeå Marine Sciences Centre, Umeå University (including a Young Researcher Award to E.B.), and the Knut and Alice Wallenberg Foundation (grant 94.160). The use of laboratory facilities as well as assistance from the staff at the Umeå Marine Sciences Centre is gratefully acknowledged. Anh Minh Nguyen and Helen Genberg are gratefully acknowledged for assistance with the experimental work.

\section{Author contributions}

S.J., U.S., M.B.N., E.L., A.A. and E.B. designed the study. S.J. and E.B. carried out the experimental work and data analysis. U.S., M.B.N., E.L. and A.A. contributed with data interpretation. S.J., U.S., M.B.N. and E.B. wrote the paper.

\section{Additional information}

Supplementary Information accompanies this paper at http://www.nature.com/ naturecommunications

Competing financial interests: The authors declare no competing financial interests.

Reprints and permission information is available online at http://npg.nature.com/ reprintsandpermissions/

How to cite this article: Jonsson, S. et al. Differentiated availability of geochemical mercury pools controls methylmercury levels in estuarine sediment and biota. Nat Commun. 5:4624 doi: 10.1038/ncomms5624 (2014). 